\title{
HUBERT WINDISCH
}

\section{Być dzisiaj Kościołem w Niemczech}

Ogólna analiza sytuacji Kościoła w Niemczech pozwala sformulować następujaca tezę: Obserwujemy proces szybkiego kurczenia się wplywu chrześcijaństwa i Kościola na życie spoleczne, tak pod względem ilościowym jak i jakościowym. Poniższy artykul stanowi próbę oceny prezentowanej tezy.

\section{Aspekt ilościowy lub strona zewnętrzna tezy}

Z danych Federalnego Urzędu Statystycznego wynika, że pod względem przynależności religijnej spoleczeństwo niemieckie dzieli się na trzy części. Okoto 1/3 spoleczeństwa należy nominalnie do Kościoła katolickiego, 1/3 do Kościolów protestanckich i $1 / 3$ nie deklaruje żadnych związków z religia. Jeżeli chodzi o wyznawców islamu i judaizmu, nie mają oni liczebnie znaczenia. Prognozy demograficzno-religijne wskazuja, że niedlugo chrześcijanie będą stanowić 1/4 spoleczeństwa. Informacje te nie sa zaskoczeniem. Z najnowszych danych statystycznych opublikowanych przez Konferencję Biskupów Niemiec wynika, że w latach 1990-2003 liczba katolików zmniejszyla się o 2,1 milional. Większość tych zmian jest wynikiem tzw. decyzji czlonka czyli wystapieniem z Kościola (Mitgliedschaftsentscheidung). Zmniejsza się także liczba chrztów. W porównaniu z rokiem 1990 liczba chrztów w 2003 r. zmalala o 31,3\%. Z grona dzieci, które kilka lat wcześniej przyjęly I Komunię, do sakramentu bierzmowania przystępuje $72 \%$ mlodych ludzi. Dramatycznie spadła w tym czasie liczba zawieranych związków malżeńskich. W stosunku do $1960 \mathrm{r}$. jedynie 1/4 katolików decyduje się na sakramentalny związek. Jeżeli chodzi o liczbę pogrzebów, to statystycznie nie ma tu większych zmian. Sytuacja ta ksztaltuje wśród wielu duszpa-

\footnotetext{
${ }^{1}$ Por. Sekretariat der Deutschen Bischofskonferenz: Katholische Kirche in Deutschland. Statistische Daten 2003 (Arbeitshilfen 193). Bonn 2005.
} 
sterzy przekonanie, że ich działalność w dużej mierze polega na przewodniczeniu obrzędom pogrzebowym. W związku z tym nie należy lekceważyć poglądu, że sluży się umierającemu Kościolowi. Pastoralno-psychologiczne skutki takich przekonań to zmęczenie, agresja czy nawet swoista mieszanka obojga. Do tego należy dodać wyraźny spadek uczestnictwa w niedzielnej Eucharystii. W 2003 r. regularnie chodzilo do kościola $15,2 \%$ katolików (u protestantów jest to zaledwie $1-2 \%$ ). Liczby te mówią same za siebie!

\section{Aspekt jakościowy, czyli strona zewnętrzna od wewnątrz}

Wymowa przedstawionych faktów nie jest jedyną przyczyną tego, że wielu pracujących w Kościele niemieckim ma omdlale ręce i drżace kolana (por. Iz 35, 3 i Hbr 12,2). Należy wskazać także na jakościowe aspekty słabnącego wplywu chrześcijaństwa i Kościola, które bardziej niż dane statystyczne budzą obawy o jego duszpastersko-teologiczna kondycję. Analizujac te jakościowe aspekty, trzeba zwrócić uwagę na dwie różne perspektywy - zewnętrzną i wewnętrzną.

\section{Perspektywa zewnętrzna strony wewnętrznej}

Sondaż internetowy drugiego programu telewizji niemieckiej (ZDF), przeprowadzony w 2002 r. na grupie ponad 350 tys. respondentów wskazuje, że Kościoły w Niemczech nie cieszą się społecznym zaufaniem i nie są też postrzegane jako zdolne do reformy. Także badania Gallupa przeprowadzone na zlecenie Światowego Forum Gospodarki pokazaly, że wśród spolecznych instytucji, pod względem prestiżu, Kościól plasuje się na ostatnim miejscu. „Niemcy ufają policji i armii" (cytat z dziennika „Die Welt” - 11.11.2002 r.). Hans-Olaf Henkel, byly przewodniczacy Federalnego Związku Niemieckich Przemyslowców, stwierdzil zwięźle w czasopiśmie "Christ in der Gegenwart": Wiara nie odgrywa już roli w tworzeniu etycznych fundamentów nowoczesnego spoleczeństwa. Glówne Kościoly stracily swą silę oddzialywania na kulturę Zachodu ${ }^{2}$. Jego zdanie podziela wielu przedstawicieli politycznej i gospodarczej elity. Michael N. Ebertz, socjolog religii z Freiburga, wskazuje na religijną dyspersję jako glówny wyznacznik dzisiejszej religijności. Proces dyspersji ma określona (...) konsekwencję. Gdy doradcy życiowi, pracownicy socjalni, lekarze, nauczyciele gimnastyki, tańca, wschodnich sztuk walki, psychologowie i psychoterapeuci, gwiazdy telewizji i producenci, a także artyści tworzq konkurencję dla duchowych przewodników utartego stylu, to przyczyniaja się do usuwania granic jakie dotychczas wyznaczaly istnienie obszarów religii, a tym samym - przynajmniej częścio-

\footnotetext{
${ }^{2}$ Por. H.-O. H e n k e l: Moral ohne Gott. Was schätze ich am Christentum? W: „Christ in der Gegenwart". R. 2002 nr 40 s. 324.
} 
wo - powodujq zanik różnic pomiędzy odmiennymi obszarami życia. Efekt tego jest taki, że każdy może być nie tylko »sektq", lecz także "teologiem" $i$ »kaptanem «; może być dla siebie "sektq", dla siebie "teologiem" i dla siebie »kaptanem «. Nie można tylko przewodniczyć wlasnym obrzędom pogrzebowym ${ }^{3}$.

Ta bardziej ironiczna uwaga odnosi się do rzeczywistości, która już istnieje. Instytuty Religioznawstwa i Islamistyki na Wolnym Uniwersytecie w Berlinie, w cyklu spotkań „Noc nauki” (11-12.06.2005 r.), przedstawily propozycję zwiazaną z pytaniem „Czym jest religia?”: Chcemy zachęcić do refleksji: macie Państwo możliwość stworzyć wlasna religię. W tym celu przygotowaliśmy "zestawy" $z$ »elementami ", którymi każdy może się postużyć. Pracownicy Instytutu chętnie odpowiedzq na wszelkie pytania.

\section{Perspektywa wewnętrzna strony wewnętrznej}

Kilka przykładów pokazuje dramatyczność tej perspektywy: Dzieci w czasie katechezy czytaja „Colgate” zamiast „Golgota”, zaś Jezusa na krzyżu identyfikują z Herkulesem. Matka jednego z dzieci, które jest przygotowywane do I Komunii, skarży się proboszczowi, że katechetka nakazala jej synowi naukę długiego wiersza na pamięć. Na pytanie proboszcza o tytul wiersza, odpowiada: nazywa się „Ojcze nasz”.

Przed Wielkanocą 2005 r. przeprowadzono w Niemczech sondaż wśród chrześcijan (katolików i protestantów). Wynika z niego, że tylko $40 \%$ z nich wierzy w zmartwychwstanie Jezusa. W kręgu osób należących do Kościola dostrzegamy, z jednej strony duży spadek wiedzy i rozumienia istoty wiary, $z$ drugiej strony - fenomen opisany przez Michaela Bongardta, który ujawnia się w postawach coraz to większej liczby ludzi jako poszukiwanie związków z Kościolem bez potrzeby wiązania się z nim ${ }^{4}$.

\section{Konsekwencje}

Należy zwrócić uwagę, że w sensie społeczno-politycznym Kościól jest postrzegany ciagle jako pożyteczny w życiu publicznym. Jednakże w istotnym punkcie, jako wspólnota religijna, stracil znaczenie (niebezpieczeństwo 1). Równocześnie istnieje niebezpieczeństwo, że Kościól ze swej strony odpowie na te zagrożenia „Syndromem Kurta Tucholsky'ego" (niebezpieczeństwo 2). Już w 1930 r. Tucholsky ironizowal: Co daje się zauwazyć w postawie obu Kościolów

${ }^{3}$ M. N. E be rtz: Kirche im Gegenwind. Zum Umbruch der religiösen Landschaft. Freiburg - Basel - Wien 1999 s. 148 nn.

${ }^{4}$ Por. H.-O. He n k e l, dz. cyt., s. 324. 
to ich wywieszony język. Bez przerwy, z zadyszkq, biegnq za czasem, aby nikt im nie umkną. "My także, my takżel" nie tak jak przed stuleciami: »My«. Socjalizm? My także. Praca z mlodzieżq? My także. Sport? My także. Takie Kościoty nic nie tworza, one dopasowuja rozwiazania juz stworzone przez innych, biorq te fragmenty, które im moga być przydatne (...). Kościól rezygnuje, nie zmienia siebie, lecz ulega zmianom ${ }^{5}$. Skutkiem tego jest „Kościół z defektem”, jak to drastycznie sformulowal Karl Barth ${ }^{6}$.

Wedlug biskupa Bazylei Kurta Kocha i innych biskupów niemieckich, nasz Kościól żyje w diasporze i w środowisku misyjnym nie tyle na podstawie liczb, ile w sensie zewnętrznych i wewnętrznych wyzwań. Szeroko rozumiany proces oczyszczania Kościola zostal zainicjowany przez Boga. Trzeba na nowo odkryć wezwanie: Czas się wypelnit i bliskie jest Królestwo Boże. Metanoeite i wierzcie $w$ ewangelię (Mk 1, 15). Jesteśmy wezwani, mówiąc biblijnie, do „wyjśsia $z$ Egiptu naszej nowoczesnej kultury - nie w sensie obronnej ucieczki lub zwrotu ku sobie - lecz jako w pewnym sensie »kulturowe nieposhuszeństwo« (B. Rootmensen): Musimy dzisiaj jako Lud Boży odkryć wlasnq tożsamość także poprzez rezygnację z mylnych dróg tej kultury, a więc poprzez gotowość do odważnego wyjścia na "pustynię", w której każdy z nas jako jednostka i cala spoleczność znów żyć będzie z podstawowego doświadczenia, a nie jedynie w kulturowym zabezpieczeniu? ${ }^{7}$ Także Jürgen Habermas wzywa do poszukiwania tożsamości, gdy pyta: Jak Kościól chrześcijański w swej wielokulturowości może zachować swq tożsamość, i jak może chrześsijańska nauka utrzymać autentyczność swego poszukiwania prawdy w dyskursywnym dialogu z konkurencyjnymi swiatopogladami? ${ }^{8}$.

Odpowiadając na to pytanie należy zauważyć i przyjać, że istnieją ogniska zapalne na styku Kościól-spoleczeństwo/państwo, które moga prowadzić do rewizji dotychczasowego konkordatowego stosunku Kościól-państwo. Ponadto należy uważnie przyjrzeć się wewnątrzkościelnym problemom, wynikajacym z dysproporcji pomiędzy stanem pożądanym a faktyczną sytuacją. Zbyt obszerne

${ }^{5}$ K. T u cholsky: „Braut- und Sportunterricht”. W: Gesammelte Werke. Bd III. Reinbek bei Hamburg 1961 s. 410.

${ }^{6}$ Por. K. B a r th: Das christliche Leben. Die kirchliche Dogmatik IV, 4 - Fragmente aus dem Nachlaß - Vorlesungen 1959-1961, W: K. B a r th: Gesamtausgabe II: Akademische Werke 1959_ 1961 (hg. von H.-A. D rew es und E. Jü ng e l) Zürich 1976 s. 223-235.

M. K e h l: Kirche in der Fremde. Zum Umgang mit der gegenwärtigen Situation der Kirche. ,Stimmen der Zeit". R. 1993: 118 s. 511.

${ }^{8} \mathrm{~J}$. H a berm a s: Israel und Athen oder: Wem gehört die anamnetische Vermunft? Zur Einheit in der multikulturellen Vielfalt. W: Diagnosen zur Zeit (mit Beiträgen von Johann Baptist M e t z, Günther Bernd G i n z e l, Peter G 1 o t z, Jürgen H a b e r m a s, Dorothee S ö 11 e). Düsseldorf 1994 s. 60. 
ubranie coraz mniej pasuje do kurczącego się ciala Kościoła. Za wielkimi portalami kościelnych ceremonii jawi się coraz mniej przestrzeni żywej wiary.

\section{Powrót do istoty}

Dzisiejszą trudną sytuację należy widzieć przede wszystkim jako szansę powrotu Kościola i jego duszpasterstwa do swej istoty. Jest możliwe, że - odwolując się do Lumen gentium (n. 1) - na nowo rozblyśnie tożsamość Kościola, który jest sakramentem, tzn. znakiem i narzędziem ścislej lączności pomiędzy Bogiem i ludźmi oraz ludzi pomiędzy sobą. Niezależnie od faktu, że ta tożsamość ma charakter sytuacyjny i historyczny, a więc konkretny, można wskazać na pewne stałe punkty odniesienia służby Kościola w świecie: Kościól zawsze wskazuje na tego, który jest Większy, i który go stworzyl. Na tym polega godność jego sakramentalnej struktury i wyraz danej mu samoświadomości. Kościól nie jest tu jednak władca, lecz wskazuje na szczególny sposób obecności Boga w czasie (przeszlość, teraźniejszość i przyszlość). Na tym polega ubóstwo jego slużby i właściwa jemu prostota. Ubóstwo jako mater virtutum (jak to określił św. Benedykt) nie oznacza bynajmniej przeciętności czy uleglości. W Kościele lączą się ze sobą świadomość własnej teologicznej godności i doświadczenie wlasnych antropologicznych ograniczeń. Kościól spełnia posługę bogaty swoim ubóstwem. $\mathrm{Na}$ tym polega sila jego potencjału nadziei, która powinna być doświadczalna jako wyzwanie przeżywane wewnątrz świata. Bogactwo ubóstwa Kościola staje się przydatne w świecie i dla świata ostatecznie jako nieustanne zmaganie się o wiarygodność, tzn. o poświadczoną wagę wiary w Jezusa Chrystusa.

W istocie chodzi tutaj o shużbę Bożą w posłudze Kościola. Jeżeli Kościól nie będzie czerpal z tej dynamiki, to jego służba stanie się czymś banalnym i bezowocnym. Przed Kościolem stoi nowy początek w wierze. Według Karla Bartha ujawnia się on jako kryzys. Z tego kryzysu, idąc za myślą Josepha Ratzingera, także i teraz Kościół wychodzi zwycięsko; wprawdzie wiele stracił, stanie się mniejszym, a może nawet musiałby zacząć od początku; Kościól, który nie jest wstanie wypelnić świątý wzniesionych w okresie koniunktury; Kościól, który wraz ze spadkiem liczby wiernych będzie tracił wiele ze swoich przywilejów spolecznych; Kościól, który mocniej będzie oparty na wspólnocie świadomych wyznawców i domagający się zdecydowanej postawy pojedynczych wiernych. Po przejściu tej jednak próby, z tego skierowanego do wewnqtrz i prostego Kościola, plynać będzie wielka sita. Ludzie żyjac w zaplanowanym świecie będa niezmiernie samotni. Skoro stracq poczucie obecności Boga, doświadczq najglębiej swej biedy. Wtedy to odkryja male wspólnoty wiary jako coś nowego. Jako nadzieję, która stanie się ich udzialem, jako odpowiedź na pytania, które zawsze stawiali w ukryciu. Wydaje mi się pewne, że przed Kościolem stoja ciężkie czasy. 
Waściwy kryzys jeszcze się nie rozpocząl. Należy liczyć się ze znacznymi wstrzqsami. Lecz na końcu, jestem tego pewien, pozostanie: nie Kościól kultu politycznego (...). lecz Kościól wiary. $Z$ pewnościq nie będzie na tyle dominujqcq sita, jakq byl jeszcze niedawno. Jednak na nowo rozkwitnie i będzie postrzegany przez ludzi jako ojczyzna, która daje im życie i nadzieje przekraczajaca śmierć.

W nawiązaniu do sugestii powrotu przez Kościół ku wlasnej tożsamości, Medard Kehl przedstawia następujaca propozycje pastoralnej strategii: „Powinniśmy silniej zbliżyć do siebie i połaczyć dwa pastoralne i wyraźnie misyjne impulsy, które już sq, lecz biegnq obok siebie; chodzi tutaj o powiqzanie »duszpasterstwa szerokiego oddzialywania $z$ "duszpasterstwem spójności « bqdź intensywności $i^{10}$. W duszpasterstwie szerokiego oddzialywania chodzi o to, aby styszany byl glos chrześcijańskiej wiary ze swa humanizujacq i ogólnie spolecznq sila, gdy uwzględnia się dobro i godność konkretnego czlowieka, szczególnie młodych $i$ starszych, slabych i ofiar spolecznego rozwoju. Chodzi o to, aby Kościoly chrześcljańskie i ich orędzia nie staly się calkowicie kulturowo obcym cialem i by wskutek tego w pluralistycznej samoświadomości wspólczesnej kultury nie zostaty natychmiast zepchnięte w obszar tego, co ezoteryczno-egzotyczne, ale spotecznie bez znaczenia, bo należy do świata ruchów religijnych, ktore mogq sobie być jakie zechcq. Podstawowy motyw naszego przepowiadania zmierza ku temu, aby Kościól byl uważany za poważnego partnera $w$ rozmowie $i$ w koalicji na plaszczyźnie życia spolecznego $i w$ życiu jednostki ${ }^{11}$. Duszpasterstwo spójności zaś troszczy się o przekaz wiary i życie z wiary poprzez komunikację wewnątrz środowiska wiary, w biotopach wiary, w centrach wiary, które próbuja w harmonijny i trwały sposób połączyć wiarę Kościoła z wlasną historią życia ${ }^{12}$. Szczególnie ważne jest, aby polożyć akcent na ten drugi impuls. Jednakże w horyzoncie otwartej i szerokiej perspektywy nie można pomijać również tego pierwszego. Takiej zmiany domaga się przede wszystkim duszpasterstwo sakramentalne.

Teologiczno-pastoralna diagnoza, jak i duszpasterska terapia dla Kościola w Niemczech rodzi się ostatecznie w perspektywie Bożej obietnicy. Należy tutaj przypomnieć slowo skierowane do proroka Izajasza, które dziś trzeba na nowo rozumieć: Nie wspominajcie wydarzeń minionych, nie roztrzasajcie w myśli daw-

${ }^{9}$ J. R a t z i n g e r: Glaube und Zukunft. München ${ }^{2} 1971$ s. $124 \mathrm{nn}$.

${ }^{10}$ M. K e h l: Welche ,pastorale Strategie" braucht die deutsche Kirche heute?. W: H.-G. $\mathrm{Z}$ i e b e r $\mathrm{z}$ (Hg.): Erosion des christlichen Glaubens? Umfragen, Hintergrïnde und Stellungnahmen zum ,Kulturverlust des Religiösen“. Münster 2004 s. 124.

${ }^{11}$ Tamże, s. $124 \mathrm{nn}$.

${ }^{12}$ Por. tamże, s. $126 \mathrm{nn}$. 
nych rzeczy. Oto ja dokonuję rzeczy nowej: pojawia się wlaśnie. Czyż jej nie poznajecie? (Iz 43, 18-19).

Thumaczyl z języka niemieckiego: GRZEGORZ ZARAZIŃSKI 
